\title{
ÇAĞIMIZIN MESLEK HASTALIĞI MOBBING VE YAPI SEKTÖRÜNDE BİR ARAŞTIRMA
}

\author{
Savaş BAYRAM $^{1}$, Z. Özlem PARLAK BİÇER ${ }^{2}$
}

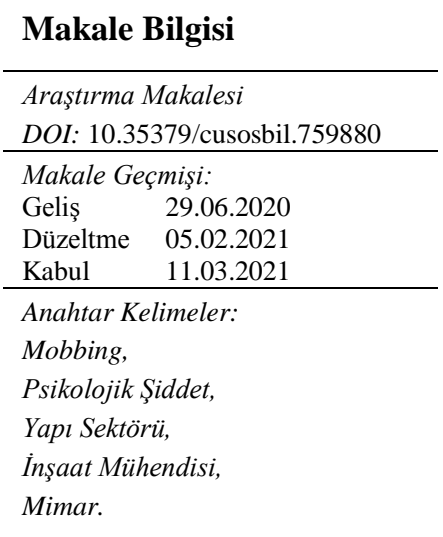

ÖZ

İş hayatında gittikçe artmakta olan psikososyal problemlerden birisini, "çağımızın meslek hastalığı' olarak tanımlanan 'mobbing' oluşturmaktadır. Her ne kadar bilimsel literatüre 1980'li yıllarda girmis bir kavram olsa da, mobbing günümüz çalıșma hayatında sık karşlaşılan ancak çalışanlar tarafindan tam olarak anlaşılmayan bir kavramdır. Mobbing, birçok insan tarafindan çözülemeyen bir sorun olarak görülmektedir. Bu durum yapı sektöründe de oldukça yaygındır. Bu çalıșmada, yapı sektöründeki mobbing probleminin, sektörde önemli rolleri olan inşaat mühendisleri ve mimarlar açısından önemi ele alınmıștır. Ayrıca, daha açık ve özlü bir yaklaşım sağlanması ve bulguların literatür ile kıyaslanması amaçlanmıştır. Sektör çalışanlarının mobbing farkındalıklarını, mobbing maruziyet düzeylerini ve mobbinge maruz kaldıklarında ne gibi yollara başvurduklarını belirlemek de çalıșmanın diğer amaçları arasındadır. Sonuç olarak; çalışanların çoğunlukla mobbing kavramını bildiklerini düșünmelerine rağmen konuya hâkim olmadıkları belirlenmiștir. Bunun yanında, Leymann'ın Psikolojik Terör Tipolojisi (LIPT) sinıflandırmasına ikinci grup maruziyet olarak tanımlanan 'sosyal ilişkilere yönelik saldırılar' maruziyeti yaşadıkları tespit edilmiştir.

\section{MOBBING, TODAY'S OCCUPATIONAL DISEASE AND A RESEARCH IN THE BUILDING SECTOR}

\begin{tabular}{l} 
Article Info \\
\hline Research Article \\
DOI: $10.35379 /$ cusosbil.759880 \\
\hline Article History: \\
Received 29.06.2020 \\
Revised $\quad 05.02 .2021$ \\
Accepted 11.03 .2021 \\
\hline Keywords: \\
Mobbing, \\
Psychological Violence, \\
Building Sector, \\
Civil Engineer, \\
Architect. \\
\hline
\end{tabular}

\begin{abstract}
Mobbing, one of the increasing psychosocial problems in work life, is defined as 'occupational disease of today'. Although it was introduced in the $1980 \mathrm{~s}$, mobbing is a concept that is very common in the work-life but not fully understood among employees. Mobbing is seen as a problem that cannot be solved by many people. This situation is quite common also in the building sector. In this study, the importance of the mobbing problem in the building sector for civil engineers and architects, who have important roles in the industry, is discussed. In addition, it is aimed to provide a clearer and more concise approach and to compare the findings with the literature. The other objectives of the study are to determine the awareness of mobbing, exposure levels of mobbing and the ways in which they apply when exposed to mobbing. It was found that although the respondents think they know the concept of mobbing, they do not dominate the subject. In addition, the respondents experienced 'effects on social contacts' which is defined as the second group exposure to the Leymann Inventory of Psychological Terror (LIPT) classification.
\end{abstract}

\footnotetext{
${ }^{1}$ Doç. Dr., Erciyes Üniversitesi, Mühendislik Fakültesi, İnşaat Mühendisliği Bölümü, sbayram@erciyes.edu.tr ORCID ID: 0000-0002-01536750

${ }^{2}$ Doç. Dr., Erciyes Üniversitesi, Mimarlık Fakültesi, Mimarlık Bölümü, parlako@erciyes.edu.tr ORCID ID: 0000-0002-9700-2226 Alıntılamk için/Cite as: Bayram, S., Parlak Biçer, Z. Ö. (2021), Çağımızın Meslek Hastalığı Mobbing Ve Yapı Sektöründe Bir Araştırma, Çukurova Üniversitesi Sosyal Bilimler Enstitüsü Dergisi, 30 (1), Sayfa 58-67.
} 
Çukurova Üniversitesi Sosyal Bilimler Enstitüsü Dergisi, Cilt 30, Say1 1, 2021, Sayfa 58-67

\section{GIRIS}

İş hayatında meydana gelen önemli değişimler, son yıllarda iş sağlığı ve güvenliği (İSG) bünyesinde yeni risk faktörlerinin ortaya çıkmasına neden olmuştur. Psikososyal risk faktörleri; İSG alanındaki fiziksel, biyolojik ve kimyasal risklere nazaran daha az bilinen bir risk faktörüdür (Korkut, 2014). Ancak iş hayatında gittikçe artmakta olan psikososyal problemlerin birisini de, 'çağımızın meslek hastalığı' olarak tanımlanan 'mobbing' oluşturmaktadır. Türkçe'de; psikolojik şiddet (Aydın vd., 2007), işyeri sendromu (Gün, 2010), bezdiri (Candan ve İnce, 2014), psikolojik taciz/psikolojik terör (Genç ve Erdiş, 2015), yıldırma/zorbalık (Gümüşburun Ayalp ve Arslan, 2016), vb. farklı tanımlar şeklinde kullanılan mobbing kavramı, 1960'lı y1llarda Konrad Lorenz tarafından hayvanların kendi aralarında ya da bir yabancıya karşı uyguladıkları taciz davranışı şeklinde tanımlanmıştır (Eser, 2008). 1970'lerde ise İsveçli bilim adamı Peter Paul Heinemann tarafından, okul yaşantısında çocukların birbirleri ile olan zorbalık ilişkilerini tanımlamakta kullanılmıştır (Heinemann, 1972). Ancak daha sonra yapılan araştırmalar mobbingin sadece çocuklar arasında yaşanmadığını ortaya koymuştur. 1980'li yıllarda, mobbing konusunda yapılan bilimsel çalışmaların öncülerinden olan Heinz Leymann, "İş Hayatında Güvenlik ve Sağlık" konulu raporda mobbing kavramını ele almış ve kavramını bilimsel literature kazandırmıştır (Tınaz vd., 2008). Leymann, "mobbing" terimini iş hayatındaki baskı, şiddet ve yıldırma hareketlerini tanımlamak için kullanmıştır (Leymann, 1990; 1996). Esasen örgütlenmenin olduğu her yerde mobbing olgusu daima var olmuş, ancak mobbing konusundaki bilinç veya farkındalık, kavramın tanımlandığı ve çerçevesinin çizildiği 1980’li yıllara kadar var olmamıştır (Tutar ve Uslu, 2018).

Mobbing, maddi ve maddi olmayan yönleriyle ele alınması gereken geniş çaplı bir problemdir (Bakırcıoğlu ve Acar, 2012). Hatta, günümüzde kişinin intihar etmesine dahi sebep olabilecek bir süreç olarak gösterilmektedir (Kaya, 2015). Leymann, problemin vehametini; "Batı dünyasının ileri düzeyde sanayileşmiş toplumlarında işyerleri, bireylerin mahkemeye sevk edilme korkusu yaşamaksızın birbirlerini öldürebilecekleri, kalan tek savaş alanıdır." cümlesi ile ifade etmiştir (Leymann, 2019). Günümüzde yapılmış ve yapılmakta olan araştırmalar; mobbing kavramının bireyler, aileler, örgütler ve toplum üzerinde bilinenden çok daha fazla olumsuz etkilerinin olduğunu ortaya koymaktadır (Davenport vd., 2003). Ancak her ne kadar Türkiye'de mobbing farkındalığg sağlanmış gibi görünse de, mobbing kavramı hâlâ yanlış algılanabilmektedir. Mobbing, pek çok durumda, işyerlerinde yaşanan; çatışma, şiddet ve cinsel taciz gibi olgularla karıştırılmaktadır (Çukur, 2018). Mobbingden söz edilebilmesi için bir anlık bir eylem ya da davranıştan ziyade, 'sistematik' bir hareketin varlığ 1 gerekmektedir. Bu nedenle işyerinde maruz kalınan her tür kötü davranış, nezaketsizlik ya da münferit olarak gerçekleştirilen bir davranış 'mobbing' olarak kabul edilmemektedir (Bakırcığlu ve Acar, 2012).

Mobbing, çalışanlara astları (dikey), eşitleri (yatay) ya da üstleri (düşey) tarafından uygulanabilir. Kişinin olanakları, eğitimleri, bütçesi kısıtlanabilir, yükselmesi engellenebilir, kişi alaya alınabilir, aşağılanabilir, toplantılara çağrılmayabilir, dişlanabilir ve kişiye hakaret edilir (Korkut, 2014). Leymann tarafından, 'Leymann'ın Psikolojik Terör Tipolojisi' (LIPT) olarak bilinen ve davranışın temel yapısına göre 45 farklı mobbing davranış özelliği tanımlamış olup, bunlar beş ana grupta toplanmıştır (Yiğit, 2016; Tutar ve Uslu, 2018). En genel hâli ile bu özellikler Tablo 1'de, etki alanları ve sonuçları ise Tablo 2'de özetlenmiştir. Konu ile ilgili yapılan çalışmaların da genellikle bu tipolojiyi kullandıkları ifade edilebilir.

Tablo 1. Mobbing Davranıs Özellikleri (Leymann, 1993; Tetik, 2010)

\begin{tabular}{|c|c|}
\hline Grup & Tanım \\
\hline 1 & $\begin{array}{l}\text { Kendini göstermesini ve iletişimini engellemek (iletişim olanaklarını olumsuz etkileyen } \\
\text { davranışlar) }\end{array}$ \\
\hline 2 & $\begin{array}{l}\text { Sosyal ilişkilerden yalıtmak (sosyal ilişkiler kurma olanaklarını olumsuz etkileyen } \\
\text { davranışlar) }\end{array}$ \\
\hline 3 & Saygınlığına saldırıda bulunmak (kişisel saygınlığını olumsuz etkileyen davranışlar) \\
\hline 4 & $\begin{array}{l}\text { Yaşam kalitesine ve mesleki duruma saldırıda bulunmak (mesleki konumunu olumsuz } \\
\text { etkileyen davranışlar) }\end{array}$ \\
\hline 5 & Doğrudan sağlığa saldırıda bulunmak (fiziksel sağlığını olumsuz etkileyen davranışlar) \\
\hline
\end{tabular}


Çukurova Üniversitesi Sosyal Bilimler Enstitüsü Dergisi, Cilt 30, Sayı 1, 2021, Sayfa 58-67

Tablo 2. Mobbing Etkileri (Davenport vd., 2003)

\begin{tabular}{|c|l|}
\hline Etki Alanı & Sonuç \\
\hline Mağdur & $\begin{array}{l}\text { Aşırı strese bağlı fiziksel ve psikolojik rahatsızlıklar ve intihar ile } \\
\text { sonuçlanabilen travmalar }\end{array}$ \\
\hline Aileler & Mutsuz ebeveynler ve çarpık yetişen çocuklar, artan boşanmalar \\
\hline Örgütler & $\begin{array}{l}\text { Anlaşmazlıklar, hastalıklı şirket kültürü, düşük moral ve kısıtlanmış } \\
\text { yaratıcılık }\end{array}$ \\
\hline Toplum & Mutsuz bireyler ve politik kaygısızlık \\
\hline
\end{tabular}

Türk hukuk sisteminde mobbing kavramı yakın bir geçmişe sahip olmakla birlikte, mobbing ile mücadele adına kayda değer aşamalar katedilmektedir. Ülkemizde, mobbing kapsamındaki ilk yargı kararı 2006 yılında verilmiştir (Altun vd., 2017). En önemli adımlar ise, 2011 yılında yayımlanan 6098 sayılı Türk Borçlar Kanunu ile 2016 yılında yayımlanan 6701 sayılı Türkiye İnsan Hakları ve Eşitlik Kurumu Kanunu'nun yürürlüğe girmeleri ile atılmıştır (Tutar ve Uslu, 2018). İstatistiksel olarak; Çalışma ve Sosyal Güvenlik Bakanlığ́ ALO 170 hattına, Mart 2011 ile 2013 tarihleri arasında toplam 5.890 adet işyerinde mobbing başvurusu yapılmıştır. Buna göre başvuruların 2/3'ü özel sektörden, 1/3'ü kamu sektöründen gelmiştir (Geleri, 2013). Daha geniş kapsamlı olarak ise Mart 2011 ile 2018 tarihleri arasında 70 bini aşkın mobbing şikayetinin yapıldığı, bu şikayetlerin \%20'sinin istifaya zorlandıkları belirlenmiştir. Kamu Görevlileri Etik Kurulu'na yapılan başvurular açısından ise; 2016 yılında yapılan 145 başvurunun 30’u (\%21), 2017 yılında yapılan 126 başvurunun 23'ü (\%18) mobbing kapsamındadır (Kamu Görevlileri Etik Kurulu, 2018). Bu veriler kayıtlanmış veriler olup, maalesef mobbing probleminin çok daha yaygın olduğu bilinmektedir.

Mobbing sadece Türkiye'nin değil, bütün dünya ülkelerinin ortak problemidir. Yapılan araştırmalar, ABD'de çalışan her beş kişiden birinin mobbing mağduru olduğunu göstermektedir (Tınaz vd., 2008). ABD'de mobbinge karşı özel olarak yapılan yasal bir düzenleme olmamakla birlikte, mobbing ile ilgili davalarda ayrımcılık hükümlerinin kıyasen uygulandığı bilinmektedir. AB üyesi ülkelerde ise özellikle sendikaların mobbing karşıtı yasaların yürürlüğe girmesi için çalışma yaptıkları bilinmekle birlikte, bu konuda en büyük ilerlemenin kaydedildiği ülke İsveç olarak gösterilebilir. Bunun yanında Almanya'da mobbing kurbanları erken emeklilik talep edebilmekte ve mobbing kurbanlarının yardım ve destek isteyebilecekleri merkezler bulunmaktadır (Tınaz vd., 2008).

İş hayatında yaygın bir meslek hastalığı hâline gelen mobbing, Türkiye'de başta sağlık, turizm, eğitim vb. olmak üzere farklı sektörlerin çalışanları açısından birçok çalışmada ele alınmıştır. Maalesef Türkiye'nin ekonomik açıdan lokomotif sektörü, istihdam açısından sünger sektörü olan yapı sektöründe konu ile ilgili olarak gerçekleştirilen çalışmalar, bir elin parmaklarını geçmemektedir. İnşaat sektörünün çalışma zamanlarının değişken ve sezonluk olması nedeniyle iş gücünün büyük bir kısmı, sürekli/sabit çalışmaktan ziyade, sık sı1k iş değiştiren ve uzmanlık alanına bağlı olarak (proje bazlı üretim nedeniyle) her projede sınırlı sürelerce bulunabilen çalışanlardan oluşmaktadır (Bayram, 2019). Bu nedenle mobbing olgusunun, inşaat sektöründe diğer sektörlere göre farklılık göstermesi de olağan kabul edilebilir. Yapılan az sayıdaki çalışmanın bulguları kısaca özetlenecek olursa;

Bakırcıoğlu ve Acar (2012), yapı sektöründeki firmalarda görev yapan 107 çalışan ile yaptıkları çalışmada; yaş, cinsiyet, medeni hal vb. demografik özelliklerin mobbing maruziyeti ve gösterilen tepki açısından belirleyici olduğunu tespit etmişlerdir. Acar vd. (2014), İstanbul'daki inşaat firmalarının 170 çalışanı üzerinde yaptıkları çalışmada, organizasyonel kültür ve mobbing arasında negatif bir ilişki bulunduğunu tespit etmişlerdir. Parlak Biçer vd. (2014), Kayseri'deki mimari bürolarda görev alan 85 çalışanın psikolojik sorunlarını irdeledikleri çalışmada; işe alımlarda sözleşme imzalanmamasının çalışanlar üzerinde olumsuz psikolojik etkileri bulunduğunu tespit etmişlerdir. Genç ve Erdiş (2015), Adana ilinde çalışan 111 inşaat mühendisi ile yaptıkları çalışmada; katılımcıların büyük çoğunluğunun mobbinge maruz kaldığını ancak bireysel anlamda bilinç düzeyinin henüz yeterince gelişmediğini, bu nedenle kurumsal hafizanın oluşmadığını tespit etmişlerdir. Karabal vd. (2016), İstanbul'daki inşaat firmalarının 170 beyaz yaka çalışanı üzerinde yaptıkları çalışmada, mobbing ile örgütsel yabancılaşma arasında pozitif yönlü ve güçlü bir ilişkinin olduğunu tespit etmişlerdir. Başağa vd. (2019), Trabzon ve Rize illerinde çalışan 214 inşaat mühendisi ile yaptıkları çalışmada, mobbing algıları 


\section{Çukurova Üniversitesi Sosyal Bilimler Enstitüsü Dergisi, Cilt 30, Sayı 1, 2021, Sayfa 58-67}

hakkındaki tutumların çalışılan işteki çalı̧̧ma sürelerine göre dikkate değer bir farklılık gösterdiğini tespit etmişlerdir.

Yapı sektöründe mobbing konusunda yapılan çalışmalar genellikle belli şehirlerle sınırlı kalmış olup, bu tür çalışmaların farklı örneklemlerle yaygınlaştırılması gerektiği düşünülmektedir. Bunun yanında, farklı eğitim seviyelerindeki çalışanların ortak yaklaşımlarından ziyade, aynı eğitim seviyesinde ve müşterek çalışan meslek gruplarının dikkate alınmasının daha anlamlı bir yaklaşım olabileceği öngörülmektedir. Bu çalışmada, yapı sektöründeki mobbing probleminin, sektörde önemli rolleri olan inşaat mühendisleri ve mimarlar açısından önemi ele alınmıştır. Ayrıca uygulama olarak, sıklıkla kullanılan ve nispeten uzun olan LIPT yaklaşımının dışına çıkılarak daha net ve öz bir yaklaşım ortaya konulması ve bulguların literatür ile kıyaslanması amaçlanmıştır. Çalışmanın sınırlılıkları; yapı sektöründe çalışan tekniker, teknisyen, surveyan, usta, işçi vb. meslek gruplarının kapsam dışında bırakılması ve bu nedenle örneklem büyüklüğünün beklenenden küçük kalması olarak gösterilebilir.

\section{YÖNTEM}

Çalışma kapsamında veri toplama yöntemi olarak anket formundan yararlanılmıştır. Bu kapsamda katılımcıların mobbing ile ilgili bilgileri, çalı̧̧ıkları işyerinde ne gibi olumsuz yaklaşımlara maruz kaldıkları, eğer mobbinge uğradıklarını düşünüyorlarsa bu duruma nasıl bir tepki verdikleri ve ortaya çıkan problem sonucunda sosyal hayatlarının nasıl etkilendiği hususlarına yönelik sorular belirlenmiştir. Katılımcılara toplam 27 soru yöneltilmiş̧ir. Sorular üç ana bölümde toplanmıştır. İlk bölümde katılımcıların demografik özellikleri, altı soru kapsamında ortaya konulmaya çalı̧̧ılmıştır. İkinci bölümde ise mobbing algısına yönelik 14 soru hazırlanmıştır. Üçüncü ve son bölümde ise mobbing maruziyetine yönelik yedi soru oluşturulmuştur.

Anket çalışması kapsamında geri dönüş maalesef beklenen düzeyde olmamıştır. Bunun sebebinin de eğer cevapladığı duyulursa işyerinde kötü davranışa maruz kalma ve/veya çoğunlukla işten atılma korkusu olduğu düşünülmektedir. Anket çalışmasının örneklemini 21'i mimar (\%29) ve 52'si (\%71) inşaat mühendisi olmak üzere 73 (\%100) çalışan oluşturmaktadır. Yöntem olarak ise 52 çalışandan Google Formlar üzerinden, 13 çalışandan Online Anketler web sitesi üzerinden ve sekiz çalışandan yüz yüze görüşme kapsamında geri dönüş alınmıştır.

Araştırmanın ana kütlesini, Türk yapı sektöründe aktif olarak çalışan inşaat mühendisleri ve mimarlar oluşturmaktadır. Türk Mühendis ve Mimar Odaları Birliği (TMMOB)'ne kayıtlı yaklaşık 100.000 inşaat mühendisi ve 50.000 mimar bulunmaktadır. Bunların \%10'u aktif olarak çalışmamaktadır. Bu nedenle, ana kütleyi yaklaşık 135.000 inşaat mühendisi ve mimar oluşturmaktadır. Araştırma teknikleri uygulanırken; örnekleme ve tam sayım olmak üzere iki temel yol izlenmektedir (Gözüm, 2017). Çalı̧̧ma kapsamında tam sayım mümkün olmadığı için örnekleme yoluna gidilmiştir. Ana kütleden \% $\% 5$ 'lik güvenilirlik sınırları içerisinde ve \%11'lik hata payı öngörülerek, belirlenen örneklem büyüklüğü 73 olarak elde edilmiştir. Böylece örneklemin, ana kütlenin yüzde 0,05 'ini temsil ettiği ifade edilebilir.

\section{BULGULAR}

Güvenilirlik analizi, daha önceden belirlenmiş bir ölçek türüne göre hazırlanmış ankete verilen yanıtların tutarlılığını ölçer. Burada tutarlılıktan kasıt, sadece ölçeğe uygun olarak sıralanabilir ölçekte (ordinal scale) yanıtlar içeren sorulara verilen yanıtların tutarlılı̆̆ıdır. Örneğin anketin cinsiyet, gelir veya evet/hayır cevabı verilen sorularına güvenilirlik analizi uygulanamaz. Ancak bu çalışmada olduğu gibi, beşli likert ölçeği ile ( 1 : hiç, 5: her zaman) sıralanabilen yanttlar güvenilirlik analizine tabi tutulabilir.

Güvenilirlik analizi için kullanılan temel yaklaşım, Cronbach Alpha $(\alpha)$ değerinin hesaplanmasıdır. Her bir madde için tek bir $\alpha$ değeri olabileceği gibi, tüm soruların ortalama bir $\alpha$ değeri de olabilir. Tüm sorular için elde edilen $\alpha$ değeri o anketin toplam güvenilirliğini gösterir ve $0,70^{\prime}$ den büyük olması beklenir. Bu değerden düşük $\alpha$ değerleri anketin zayıf güvenilirliği olduğunu göstermekte olup, $\alpha>0,80$ durumu ise anketin yüksek güvenilirliğe sahip olduğunu göstermektedir (Bernardi, 1994). $\alpha$ değeri şu şekilde formüle edilir:

$$
\alpha=\left(\frac{k}{k-1}\right) x\left(1-\frac{\sum_{i=1}^{k} \sigma^{2} y i}{\sigma^{2} x}\right)
$$

Burada; $k$ : madde sayısı (likert ölçeği ile hazırlanan soru saylsı), $\sigma_{y i}^{2}$ : i. maddenin toplam örneklemdeki varyansı, $\sigma_{x}^{2}$ : toplam test skorunun varyansı olarak ifade edilir. Beşli likert ölçeği kullanılan çalışmanın ikinci bölümündeki 13 soru için $\alpha$ değeri şu şekilde hesaplanmıştır; 
$\alpha=\left(\frac{13}{13-1}\right) x\left(1-\frac{14,83}{90,91}\right)=0,91$

Sınır değer olarak 0,80 değeri göz önünde bulundurulduğunda, ölçeğin yüksek güvenilirliğe sahip olduğu söylenebilir.

\section{A. Demografik Özellikler}

Katılımcıların mesleki dağılımları göz önüne alındığında, inşaat mühendislerinin yanıtların dağılımındaki etkisi daha fazladır. Katılımcıların \%29'unu (21) kadınlar, \%71'ini (52) erkekler oluşturmaktadır. Benzer şekilde, erkek katılımcıların yanıtların dağılımındaki etkisinin daha fazla olduğu ifade edilebilir. Katılımcıların \%59'u (43) şantiye, \%41'i (30) ofis (büro) ortamında çalışmaktadır. Katılımcıların \%29'u (21) İstanbul'da, \%21'i (15) Kayseri'de, \%8'i (6) Ankara'da çalışmakta olup, bu üç şehir örneklemin \%58'ini oluşturmaktadır. Bunlar dışındaki 22 farklı şehirden elde edilen frekanslar üç ve altıdır. Bu nedenle, örneklemin Türkiye genelini temsil ettiği düşünülmektedir. Demografik özellik olarak belirlenen toplam altı sorudan; meslek, cinsiyet, çalışma şekli ve çalışılan şehir dışındaki son ikisi, mesleki deneyim ve işyeri değişikliği olarak belirlenmiş ve Şekil 1 ile 2'de sunulmuştur.

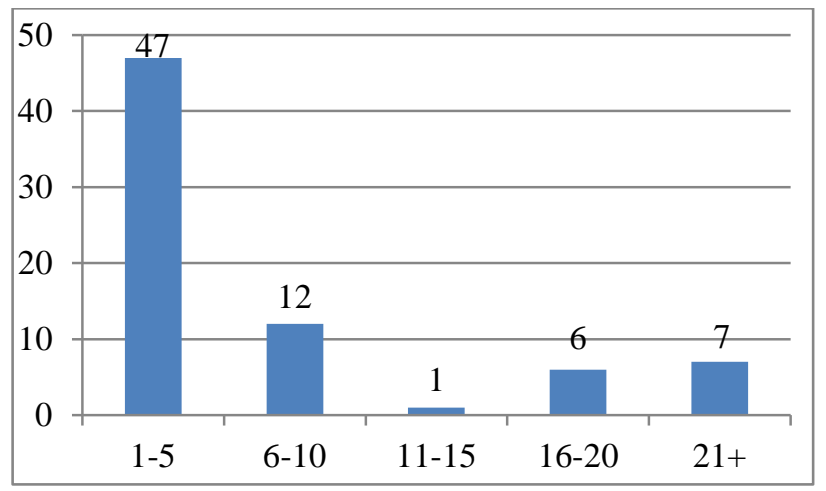

Şekil 1. Mesleki Deneyim (yıl)

Katılımcıların \%64'ü 5 yıl veya daha az süreli iş tecrübesine sahiptir. Bu nedenle, nispeten yeni mezunların, yanıtların dağılımındaki etkisinin daha fazla olduğu ifade edilebilir.

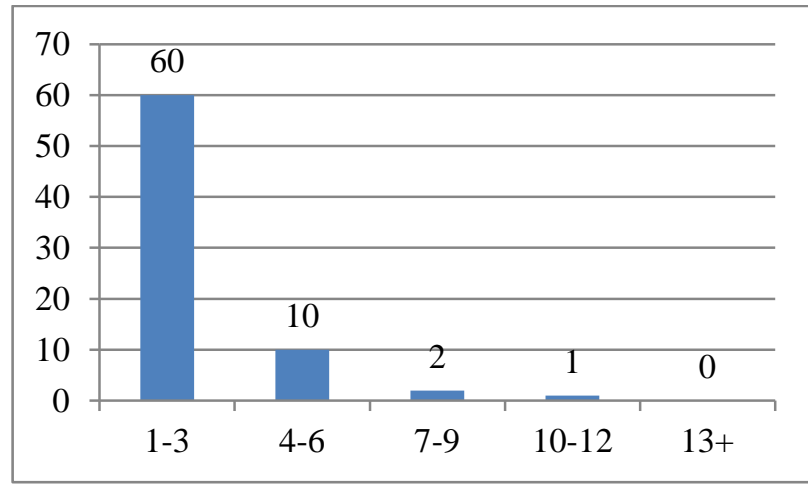

Şekil 2. İşyeri Değişikliği Sayısı (adet)

Katılımcıların \%82'si, meslek hayatında en fazla üç iş yeri değiştirdiğini ifade etmiştir. Bu da, büyük bir kısmın çok fazla iş değişikliği yapmadığını göstermektedir.

\section{B. Mobbing Farkındalığı}

Anket çalışmasının ikinci bölümünü oluşturan mobbing farkındalığı kapsamında, 73 katılımcıya toplam 14 soru yöneltilmiştir. Beşli likert ölçeğinden farklı olarak üç seçenekli (evet, hayır, sadece kelimeyi duydum) olarak yöneltilen ilk soru kapsamında; katılımcıların \%74'ü (54) mobbing kavramını bildiğini, \%16's1 (12) 
Çukurova Üniversitesi Sosyal Bilimler Enstitüsü Dergisi, Cilt 30, Sayı 1, 2021, Sayfa 58-67

bilmediğini, \%10’u (7) ise sadece kelimeyi duyduğunu ifade etmiştir. Bu verilere göre, her dört mühendis ve mimarın üçünde mobbing bilincinin var olduğu ve buradan yola çıkılarak Türk yap1 sektöründe mobbing farkındalığı oluştuğu savunulabilir. İkinci sorudan 14. soruya kadar olan toplam 13 soru kapsamında, (1: hiç, 5: her zaman) dâhilinde verilen cevapların ortalama $(\bar{x})$ ve standart sapma $(\sigma)$ değerleri, Tablo 3 'te verilmiştir.

Tablo 3. İkinci Bölüm Kapsamındaki Sonuçlar

\begin{tabular}{|c|c|c|c|}
\hline No & Açıklama & $(\overline{\mathbf{x}})$ & $(\sigma)$ \\
\hline- & \multicolumn{3}{|l|}{ Daha önce çalıştığınız bir iş yerinde; } \\
\hline 2.2. & Sağlığınıza yönelik bir saldırı oldu mu? & 1,343 & 0,731 \\
\hline 2.3 . & $\begin{array}{l}\text { Sosyal hayatınıza yönelik bir saldırı oldu } \\
\text { mu? }\end{array}$ & 1,986 & 1,286 \\
\hline 2.4. & $\begin{array}{l}\text { Sosyal ilişkilerinizi olumsuz etkileyecek } \\
\text { bir girişimde bulunuldu mu? }\end{array}$ & 1,890 & 1,035 \\
\hline 2.5 . & $\begin{array}{l}\text { Mesleki kariyerinizi olumsuz etkileyecek } \\
\text { bir davranışta bulunuldu mu? }\end{array}$ & 1,986 & 1,047 \\
\hline 2.6. & $\begin{array}{l}\text { Yaptığınız işi eleştirenler, olumsuz yorum } \\
\text { yapanlar oldu mu? }\end{array}$ & 2,616 & 1,049 \\
\hline 2.7. & $\begin{array}{l}\text { Konuşmaya başladığınızda sözünüzün } \\
\text { kasıtlı olarak kesildiği durumlarla } \\
\text { karşılaştınız mı? }\end{array}$ & 2,288 & 1,124 \\
\hline 2.8. & $\begin{array}{l}\text { Siz çalışırken her hareketinizin takip } \\
\text { edildiği durumlar oldu mu? }\end{array}$ & 2,562 & 1,105 \\
\hline 2.9. & $\begin{array}{l}\text { Kendinizi ifade etme firsatınız engellendi } \\
\text { mi? }\end{array}$ & 2,260 & 1,055 \\
\hline 2.10 & $\begin{array}{l}\text { Arkanızdan konuşuldu mu? Ya da } \\
\text { konuşulduğunu düşünüyor musunuz? }\end{array}$ & 2,918 & 1,331 \\
\hline 2.11 & $\begin{array}{l}\text { Uzmanlık düzeyinizin altındaki } \\
\text { görevlerde çalıştırıldınız mı? }\end{array}$ & 2,466 & 1,068 \\
\hline 2.12 & Aldığınız kararlardan şüphe edildi mi? & 2,356 & 0,872 \\
\hline 2.13 & $\begin{array}{l}\text { İşle ilgili önemli haber veya gelişmelerin } \\
\text { dışında bırakıldınız mı? }\end{array}$ & 2,219 & 1,083 \\
\hline 2.14 & Sizi işten ayrılmaya zorlayanlar oldu mu? & 1,712 & 0,964 \\
\hline
\end{tabular}

Ortalama değeri en düşük olan soru, ikinci soru olarak görülmektedir. Aynı sorunun standart sapmasının da en düşük olması, katılımcıların sağlıklarına yönelik bir saldırı olmadığı yönünde fikir birliğinde olduklarını göstermektedir. Ortalama değeri en yüksek olan soru ise 10. sorudur. Aynı sorunun standart sapmasının da en yüksek olması, katılımcıların en iyi ihtimalle işyerinde arkalarından konuşulduğunu düşündüklerini ancak verilen cevapların da değişken olduğunu göstermektedir.

\section{Mobbing Maruziyeti}

Anket çalışmasının üçüncü bölümünü oluşturan mobbing maruziyeti kapsamında, katılımcılara isteğe bağlı olarak toplam yedi soru yöneltilmiştir. Bu kapsamda sorular ve cevap seçenekleri Tablo 4'te verilmiştir.

Tablo 4. Üçüncü Bölüm Kapsamındaki Sonuçlar

\begin{tabular}{|c|c|c|c|}
\hline No & Açıklama & $\begin{array}{l}\text { Frekans } \\
(\mathbf{N})\end{array}$ & $\begin{array}{c}\text { Cevap } \\
\text { seçenekleri }\end{array}$ \\
\hline- & Eğer mobbinge uğradıysanız; & & \\
\hline 3.1 . & $\begin{array}{l}\text { Bu duruma nasıl karşılık verdiğinizi } \\
\text { kısaca açıklayınız. }\end{array}$ & 21 & Ucu açık \\
\hline 3.2 . & $\begin{array}{l}\text { Verdiğiniz karşıllık olumlu sonuçlar } \\
\text { doğurdu mu? }\end{array}$ & 52 & Evet, Hayır \\
\hline 3.3 . & $\begin{array}{l}\text { İş hayatınızın tamamında, maruz } \\
\text { kaldığınız mobbing toplam ne kadar } \\
\text { sürdü? }\end{array}$ & 47 & $\begin{array}{l}0-6 \text { ay, } 7-11 \text { ay, } \\
1-2 \text { y1l, } 3-4 \text { y1l, } \\
5+\text { y1l }\end{array}$ \\
\hline 3.4 . & $\begin{array}{l}\text { Size mobbing uygulayan kişinin size } \\
\text { göre mevkisi neydi? }\end{array}$ & 48 & $\begin{array}{l}\text { Üst, Alt, Aynı } \\
\text { mevki }\end{array}$ \\
\hline 3.5 . & Bu durumu iş yeri dışında bir & 48 & Evet, Hayır \\
\hline
\end{tabular}


Çukurova Üniversitesi Sosyal Bilimler Enstitüsü Dergisi, Cilt 30, Sayı 1, 2021, Sayfa 58-67

\begin{tabular}{|c|l|c|l|}
\hline profesyonelle görüş̧ünüz mü? & & \\
\hline 3.6. & $\begin{array}{l}\text { Hukuki yollardan bu durumu } \\
\text { düzeltmek için girişimleriniz oldu } \\
\text { mu? }\end{array}$ & 46 & Evet, Hayır \\
\hline 3.7. & $\begin{array}{l}\text { Bu durumdan ailenize veya işyeri } \\
\text { dişından birine bahsettiniz mi? }\end{array}$ & 54 & $\begin{array}{l}\text { Aile, Arkadaşlar, } \\
\text { Psikolog, Hiç } \\
\text { kimse, Diğer }\end{array}$ \\
\hline
\end{tabular}

Birinci soru kapsamında verilen cevapların dağılımı üç ana grupta birbirine yakın olup, cevaplayanların \%38'i tepkisiz kaldığını, \%33'ü sözlü veya fiilî bir şekilde tavrını ortaya koyduğunu ve \%29’u istifa ettiğini belirtmiş̧tir. Bu sonuç, mobbinge uğrayan çalışanların bu kapsamındaki hakları konusunda net fikir sahibi olmadıklarına işaret etmektedir. Mobbing neticesinde verdikleri karşılığın olumlu sonuç doğurduğunu düşünenlerin oranı $\% 54$ iken, düşünmeyenlerin oranı $\% 46$ 'dır. Üçüncü soruda cevaplayıcıların $\% 70$ 'i maruz kaldıkları mobbingin 0-6 ay arasında sürdüğünü, $\% 30$ ’u 6 aydan daha uzun sürdüğünü beyan etmiştir. Mobbinge uğrayanların \%69'u üstlerinden, \%21'i mevkidaşlarından ve sadece \%10'u astları tarafindan mobbinge uğradığını ifade etmiş̧tir. Mobbing maruziyetleri konusunda iş yeri dışında profesyonel destek alanların oranı \%10'da, hukuki yollara başvuranların oranı \%4'te kalmaktadır. Maruziyetin dışa vurumu olarak cevaplayıcıların \%46'sı durumu arkadaşlarıyla paylaştığını beyan ederken, ailesiyle paylaşı ı̆ını beyan edenlerin oranı $\% 28$ 'de kalmıştır.

\section{TARTIŞMA}

Yapı sektörü, üst düzey eğitimli çalışanlardan kalifiye olmayan işçilere kadar farklı eğitim seviyelerindeki birçok paydaşın çalıştığı ve yoğun iş gücü gerektiren bir sektördür (Bayram, 2019). Bu noktada temel problem, üretimin proje bazlı olarak yapıldığı sektörde proje ekiplerinin geçici ve dönemsel olarak birlikte çalışabilmeleridir. Proje ekiplerinin her projede büyük oranda değişkenlik göstermesi ve süreklilik arz etmemesi, yapı sektöründe mobbing kavramının diğer sektörlerdeki gibi ele alınmasını zorlaştırmaktadır. Zira mobbing kavramında kişisel algılamalar önemli bir yer tutmaktadır. Bir kişi için mobbing olarak algılanan olumsuz olaylar, başka kişiler tarafından olumsuz şekilde algılanmayabilir (Gözüm, 2017).

Çalışma kapsamında elde edilen ve birinci bölüm olarak sunulan demografik özelliklerden en çok göze çarpanları; katılımcıların çoğunluğunun iş tecrübesinin 5 yıl veya altında olması ve çoğunluğunun meslek hayatında en fazla üç işyeri değiştirmiş olmalarıdır. Zira dinamik bir sektör olarak bilinen yapı sektöründe iş devrinin de yüksek olduğu bilinmektedir. İş devri oranının düşük kalmasının; çalıştıkları işyerinden memnun olmalarından ziyade, çoğunluğun iş tecrübesinin az olmasından kaynaklandığı düşünülmektedir.

Çalışmanın ikinci bölümü kapsamında, katılımcıların sağlıklarına yönelik saldırıların oldukça düşük kaldığının anlaş̧lması (soru 2.2.), mobbing davranış özellikleri açısından yapı sektöründe LIPT'nin beşinci gruba (doğrudan sağlığa saldırıda bulunmak) sirayet etmediğini ancak Tablo 1'de verilen ilk dört grubu kapsayabileceğini göstermektedir. Bu konunun detayları için ayrıca bir çalışma yapılabilir. Bunun yanı sıra, verilen cevapların $[(\overline{\mathrm{x}}+\sigma)-(\overline{\mathrm{x}}-\sigma)]<2,000$ aralığı dikkate alındığında; katılımcıların aldıkları kararlardan şüphe edilmediği (soru 2.12.) ve çalışanların işten ayrılmaya zorlanmadıkları (soru 2.14.) görülmektedir. Bu bulgu, Geleri (2013)'nin çalışmasındaki; mobbinge uğrayanların istifaya zorlanma konusunda şikayetçi oldukları bulgusu ile örtüşmemektedir. Ancak $[(\overline{\mathrm{x}}+\sigma)-(\overline{\mathrm{x}}-\sigma)]>2,500$ aralığında ise LIPT'nin ikinci grubu kapsamında çalışanların sosyal hayatlarına yönelik saldırıya maruz kaldıkları (soru 2.3.) ve iş yerinde arkalarından konuşulduğunu düşündükleri (soru 2.10.) anlaşılmaktadır.

Çalışmanın üçüncü ve son bölümü kapsamında; mobbinge maruz kalanların büyük oranda üstleri tarafindan mobbinge uğradıkları (soru 3.4.) ve büyük oranda tepkisiz kaldıkları (soru 3.1.), işyeri dışında avukat, psikolog vb. profesyonellerden destek almadıkları (soru 3.5.) ve hukuki yolları tercih etmedikleri (soru 3.6.) anlaşılmaktadır. Bu bulgular, mobbing maruziyetinin profesyonel destekle veya hukuki yollarla çözülebilecek bir durum olduğuna inanılmadığını göstermektedir. Mobbinge karşılık verenlerin çoğunun (soru 3.2.) da olumlu sonuç aldıklarını düşündükleri görülmektedir. Bu bölümdeki en dikkat çekici ayrıntı; cevaplayıcıların sadece \%30'unun, maruz kaldıkları mobbingin altı aydan daha uzun sürdüğünü (soru 3.3.) beyan etmiş olmalarıdır. Esasen bu bulgu, Hubert ve Veldhoven (2001)'in; mobbingin inşaat sektöründe \%33 oranında yaşandığı bulgusu ile örtüşmektedir. Diğer yandan Bakırcıoğlu (2012)'nun; inşaat sektörü çalışanlarının yaklaşık \%50'sinin mobbinge dönüşebilecek davranışlar ile düzenli olarak karşılaştığı bulgusu, bu noktada 


\section{Çukurova Üniversitesi Sosyal Bilimler Enstitüsü Dergisi, Cilt 30, Sayı 1, 2021, Sayfa 58-67}

iyimser görünmektedir. Ancak her ne kadar birinci bölümde katılımcıların 3/4'ü mobbing kavramını bildiklerini ifade etmiş olsalar da, bu bulgu mobbing kavramı hakkında net bilgi sahibi olmadıklarını göstermektedir. Ayrıyeten bu bulgu, kurumsal hafizanın oluşmaması açısından Genç ve Erdiş (2015)'in çalışması ile de benzerlik göstermektedir. Zira yapılan araştırmalar, en kısa mobbing süresinin 6 ay, ortalama uygulama süresinin 15 ay ve sürecin kalıcı ağır etkilerinin ortaya çıktığı ana dönemin ise 29-46 ay arasında olduğunu göstermektedir (Tınaz, 2006). Diğer bir önemli nokta ise, mobbinge uğrayan inşaat mühendislerinin ve mimarların $3 / 4$ ü durumu ailesi veya arkadaşları ile paylaşırken, yaklaşık beşte birinin hiç kimse ile paylaşmadığını ifade etmiş olmasıdır. Bu durum, mobbing maruziyetinin çalışanlar açısından bir suçluluk veya aciziyet belirtisi olarak yorumlanmakta olabileceğini düşündürmektedir. Halbuki mobbingle toplumsal olarak başa çıkma yöntemleri; iletişim araçları, telefon yardım hatları ve sendikalar olarak sınıflandırılmaktadır (Davenport vd., 2003).

\section{SONUÇLAR}

Farklı sektörlerde çalışan birçok kişinin kendilerine yapılan psikolojik tacizi bilimsel açıdan hâlâ bir iş yaşamı sorunu olarak görmemeleri, mobbing hakkında yeterli bir bilgi birikiminin bulunmaması ve bu konuda bilimsel çalışmaların büyük kitlelere ulaşamamasından kaynaklanabilmektedir. Ayrıca işverenlerin de konu ile ilgili yeterli bilgi ve birikime sahip olmamaları, işyerlerinde psikolojik tacizin normal bir yaşam süreci olduğu izlenimi yaratmaktadır.

Örneklemini büyük oranda yeni mezun ve fazla iş değişikliği yapmamış olan inşaat mühendisi ve mimarların oluşturduğu bu çalışmada; örneklemin iş yerinde en çok arkalarından konuşulduğundan şikayet ettikleri ve 'mobbing' ile 'arkadan konuşma' kavramlarını doğrudan ilişkilendirdikleri sonucuna ulaşılmıştır. Maalesef bu durumun, her ne kadar örneklemin \%74'ü mobbing kavramını bildiğini ifade etmiş olsa, mobbing farkındalığı açısından soru işareti oluşturduğu görülmüş̧ür. Bunun yanında örneklemin, Leymann'ın Psikolojik Terör Tipolojisi (LIPT) açısından en çok, ikinci grup maruziyet olarak tanımlanan 'sosyal ilişkilerden yalıtmak' (sosyal ilişkiler kurma olanaklarını olumsuz etkileyen davranışlar) yaklaşımına maruz kaldıkları tespit edilmiştir. Ayrıca çalışmanın örneklemini oluşturan inşaat mühendisi ve mimarların en fazla düşey mobbinge maruz kaldıkları anlaşılmakta; ancak genellikle bu duruma tepkisiz kalmaları, çalışan olarak haklarını bilmedikleri şeklinde yorumlanmaktadır. İş hayatında mobbinge maruz kalan çalışanların sadece iş hayatları değil, aynı zamanda sosyal yaşamları da olumsuz etkilenmektedir. Çalışanların psikolojileri olumsuz etkilenmekte, bu durum aile bireylerini ve dolayısıyla toplumu da etkileyebilecek büyük sorunlar ortaya çıkarmaktadır. $\mathrm{Bu}$ nedenle, her şeyden önce, mobbinge maruz kalan çalışanların haklarını çok iyi bilmeleri gerekmektedir. Mobbingin dikkate alınması gereken bir 'meslek hastalığı' olduğu tüm çalışanlar tarafindan benimsenmelidir. Bunun yanı sıra, çalışanlara ve yöneticilere gerekli mobbing eğitiminin verilmesi gerekmektedir. Bu çalışmadan da tespit edildiği üzere, özellikle mobbing davranışları ile karşılaştıklarında daha fazla tepkisiz kalma eğilimi taşıyan genç çalışanların mobbing konusunda eğitilmeleri büyük önem taşımaktadır. Tüm bunlar sağlanırken, diğer yandan çalışanlardan gelen şikâyetlerin dikkate alınması da son derece önemlidir. Çalışanlardan gelen şikâyetler doğrultusunda sorumlulara yaptırım uygulanması şarttır. Bu da ancak kurumlarda/firmalarda mobbing şikâyet ve denetim mekanizmalarının oluşturulması ve etkin bir biçimde çalıştııılması ile mümkün olabilir. Örnek vermek gerekirse, 2012 yllında Gazi Üniversitesi bünyesinde kurulan 'mobbing ofisi'nin kurumlarda/firmalarda zorunlu hâle getirilmesi düşünülebilir.

Mobbing ile mücadelede en büyük görev yasama organlarına düşmektedir. Maalesef Türkiye'de mobbing kapsamında önemli bir problem de mevzuat açısından yaşanmaktadır. Her ne kadar 6098 sayılı Türk Borçlar Kanunu ile 6701 sayılı Türkiye İnsan Hakları ve Eşitlik Kurumu Kanunu gibi pozitif düzenlemeler yapılıyor olsa da, Türkiye mobbing konusunda birçok gelişmiş ülkenin gerisinde bulunmaktadır. Daha somut adımlar atılarak, örneğin mobbing maruziyeti kavramına bir iş sağlı̆ğ ve güvenliği (ISG) problemi olarak yaklaşılarak ve mobbing eylemleri mevzuata suç olarak yansıtılarak bu konuda önemli mesafe katedilebilir. Örneğin İtalya'da, mobbing dolayısıyla ortaya çıkan rahatsızlıklar iş kazası kapsamında değerlendirilmektedir (Shallcross, 2003). Son olarak iş akitlerinin mobbing kapsamında caydırıcı maddeler eklenerek güncellenmesinin hukuki olarak önemli bir gelişme olabileceği düşünülmektedir. Henüz sınırlı sektörlerde ve sınırlı örneklemlerle bilimsel çalışmalara konu olabilen mobbing maruziyetinin yapı sektörü açısından ele alındığı ilk çalışmalardan olan bu çalışmanın, müteakip çalışmalara yol göstermesi beklenmektedir.

\section{Teşekkür}

Yazarlar, katkıları için İnşaat Mühendisi Cebrail Doğan'a teşekkür ederler. 
Çukurova Üniversitesi Sosyal Bilimler Enstitüsü Dergisi, Cilt 30, Sayı 1, 2021, Sayfa 58-67

\section{KAYNAKLAR}

Acar, P., Kıyak, M., ve Sine, B. (2014). The relationship between Organizational Culture and Mobbing: An application on construction companies. Journal of Workplace Behavioral Health, 29, 281-298.

Altun, M., Sayer, A., ve Barutçu, A. (2017). Yargı kararları, kamu görevlileri etik kurulu kararları ve ilgili mevzuat perspektifinde işyerinde psikolojik taciz (Mobbing). Türkiye Barolar Birliği Dergisi, 128, 511544.

Aydın, Ş., Şahin, N., ve Uzun, D. (2007). Örgütlerde yaşanan psikolojik şiddet sorunlarının konaklama işletmeleri açısından değerlendirilmesi. Çukurova Üniversitesi Sosyal Bilimler Enstitüsü Dergisi, 16(2), 61-74.

Bakırcıoğlu, İ. (2012). Yapı ve mimarlık hizmetleri sektörlerindeki işyerlerinde Mobing [Yüksek Lisans Tezi, İstanbul Teknik Üniversitesi].

Bakırcıoğlu, İ. ve Acar, E. (2012). Yapı ve mimarlık hizmetleri sektörlerindeki işyerlerinde Mobing. 2. Proje ve Yapım Yönetimi Kongresi, 13-16 Eylül, İzmir.

Başağa, HB, Karal, Ü. ve Temel, BA (2019). Türkiye'de inşaat mühendislerinin Mobbing algılarının belirlenmesi üzerine bir çalışma. Erzincan Üniversitesi Fen Bilimleri Enstitüsü Dergisi, 12(2), 714-733.

Bayram, S. (2019). Günümüz ve geleceğin inşaat mühendisi perspektifinden ISG farkındalığı. Z.Ö. Parlak Biçer (ed.), Akademisyenler, Profesyoneller ve Öğrenciler için Işs Sağlı̆̆l ve Güvenliği içinde (s. 295-321). Nobel Akademik Yayıncılık.

Bernardi, RA (1994). Validating research results when Cronbach's Alpha is below .70: A methodological procedure. Educational and Psychological Measurement, 54(3), 766-775.

Candan, H. ve İnce, M. (2014). Mobbingden (Bezdiri) tükenmişliğe giden yol: Çevre ve Şehircilik Bakanlı̆̆ çalışanları üzerinde bir araştırma. Çağ Üniversitesi Sosyal Bilimler Dergisi, 11(2), 56-85.

Çukur, C. (2018). Türk Hukuku ve Karşılaştırmalı Hukukta işyerinde psikolojik Taciz. TBMM Araştırma Merkezi Yayınları, No: 9.

Davenport, N., Swartz, RD ve Eliot, GP (2003). Mobbing: İşyerinde duygusal taciz (Çev.: Osman Cem Önertoy), Sistem Yayıncılık.

Eser, O. (2008). Mobbing Kavramının Türkçe serüveni. İstanbul Kültür Üniversitesi, http://turkoloji.cu.edu.tr/YENI\%20TURK\%20DILI/oktay eser_mobbing_kavrami.pdf (Erişim tarihi: 16.12.2019)

Geleri, MF (2013). Mobbingin sektörel bazda yaş ve cinsiyete göre dağılımı. https://www.muhasebenet.net/haber.php?haber_id=5833(Erişim tarihi: 22.11.2019)

Genç, O. ve Erdiş, E. (2015). İnşaat sektöründe Mobbing sorunsal1. Çukurova Üniversitesi Mühendislik Mimarlık Fakültesi Dergisi, 30(1), 215-221.

Gözüm, P. (2017). Mobbing algısı ile motivasyon ilişkisi: Erzurum ve Ankara illerinde bazı kamu ve özel kurum çalışanları üzerine bir araştırma. [Doktora Tezi, Selçuk Üniversitesi].

Gümüşburun Ayalp, G. ve Arslan, F. (2016). İnşaat mühendislerini ve mimarları demotive eden kriterler. Dicle Üniversitesi Mühendislik Fakültesi Mühendislik Dergisi, 7(1), 11-22.

Gün, H. (2010) Çalışma ortamında psikolojik taciz: işyeri sendromu (Mobbing/Bullying). Lazer Yayınları. 
Çukurova Üniversitesi Sosyal Bilimler Enstitüsü Dergisi, Cilt 30, Sayı 1, 2021, Sayfa 58-67

Heinemann, P. (1972). Mobbing-group violence by children and adults. Natur och Kultur.

Hubert, A. ve Veldhoven, M. (2001). Risk sectors for undesirable behaviour and Mobbing. European Journal of Work and Organizational Psychology, 10(4), 415-424.

Kamu Görevlileri Etik Kurulu. (2018). 2017 yılı faaliyet raporu. http://etik.gov.tr/faaliyetraporu_2017.pdf (Erişim tarihi: 21.11.2019)

Karabal, C., Sağbaş, M. ve Kaygın, E. (2016). Mobbing ile örgütsel yabancılaşma arasındaki ilişkiyi belirlemeye yönelik bir araştırma. Van Yüzüncü Yıl Üniversitesi İktisadi ve İdari Bilimler Fakültesi Dergisi, 1(1), 140-162.

Kaya, M. (2015). Mobbingin kurumsal etkileri ve maliyeti. Sayıştay Dergisi, 97, 77-88.

Korkut, AE (2014). Psikososyal risk faktörleri ve inşaat sektöründe bir çalışma [İş Sağllğı ve Güvenliği Uzmanlık Tezi, T.C. Çalışma ve Sosyal Güvenlik Bakanlığı].

Leymann, H. (1990). Mobbing and psychological terror at workplaces. Violence and Victims, 5(2), 119-126.

Leymann, H. (1993). Mobbing-Psychoterror am Arbeitsplatz und Wie Man Sich Dagegen Wehren Kann (Mobbing-Psychological Terror at Work, and How One Can Defend Oneself). Ro-wohlt, Taschenbuch Verlag GmbH, Reinbeck, Hamburg.

Leymann, H. (1996). The content and development of Mobbing at work. European Journal of Work and Organizational Psychology, 5(2), 165-184.

Leymann, H. (2019). Mobbing-Its course over time. The Mobbing Encyclopedia, (t.y.) http://www.leymann.se/English/frame.html (Erişim tarihi: 15.11.2019)

Parlak Biçer, ZÖ, Öztürk, S. ve Karaaslan, NS (2014). Kayseri'deki mimarlık bürolarında karşılaşılan fiziksel ve psikolojik sorunlar. Fifth International Science and Technology Conference (ISTEC), 18-20 Aralık, Doha, Katar.

Shallcross, L. (2003). The workplace Mobbing syndrome, response and prevention in the public sector. Workplace Mobbing Conference, 16-17 October, Brisbane, Australia.

Tetik, S. (2010). Mobbing kavramı: birey ve örgütler açısından önemi. KMÜ Sosyal ve Ekonomik Araştırmalar Dergisi, 12(18), 81-89.

Tınaz, P. (2006). İş yerinde psikolojik taciz (Mobbing). Beta Yayınları.

Tınaz, P., Bayram, F., ve Engin, H. (2008). Çalışma psikolojisi ve hukuki boyutlarıyla işyerinde psikolojik taciz. Beta Yayınları.

Tutar, H. ve Uslu, F. (2018). Mobbing Hukuku. Adalet Yayınları.

Yiğit, B. (2016). Mobbing kavramı: Kavramsal bir çerçeve. Avrasya Sosyal ve Ekonomi Araştırmaları Dergisi (ASEAD), 5(1), 32-42. 